\title{
ЕКСПРЕСІЯ ЯК ЧИННИК СТИЛЬОВОЇ ПЕРЕОРГАНІЗАЦІЇ РЕЛІГІЙНОЇ ЛЕКСИКИ
}

У статті проаналізовано роль експресії у стильовій переорієнтації релігійної лексики поза релігійною сферою. Виявлено, що характер експресії впливає на появу стилістичних відтінків (поетичного, піднесено-урочистого, розмовного, оцінного та ін.) у значеннях, які з 'являються на різних етапах розвитку релігійних лексем. Стилістичні фігури повтор і плеоназм слугують увиразненню притаманної українцям риси експресивності, поєднаної з критичною оцінкою дійсності. Саме такі давньокиївські та староукраїнські

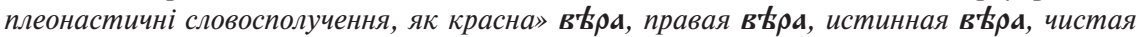

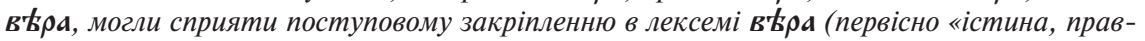
да») значення «релігія».

Ключові слова: семантика, релігійна лексика, експресивний компонент значення, стилістичний відтінок значення, плеоназм.

Kovtun A. A. Expressiveness as a Factor in the Stylistic Reorganization of Religious Vocabulary. Due to a long stay on the periphery of the public consciousness, religious vocabulary has acquired a high permeability beyond the limits of its conventional style, although in the Ukrainian language it has always been an open system, refined through its active use. This stratum of vocabulary is quite rightly attributed to those that reflect the most active manifestations of the life of Ukrainians. Despite the lively interest of domestic linguists in the functioning of religious vocabulary outside the narrow professional segment of communication, the question of the actualization of religious vocabulary in the context of its stylistic reorganization in colloquial, artistic, publicistic and mass-media Ukrainian speech remains relevant. The purpose of this study is to clarify the effect of expressiveness as a factor in the reorientation of the stylistic features of religious lexemes against the background of the preservation of religious values outside of religious discourse.

In the course of the study, it was established that, outside the religious sphere, expressiveness vividly accompanies the use of lexemes in religious meanings, while stimulating the stylistic modification of these units. The nature of expressiveness affects the emergence of new stylistic nuances (neutral $\rightarrow$ poetic, sublimely solemn, conversational, evaluative, etc.) that appear at a certain stage of development of the religious lexemes semantics due to the strengthening of separate semes of meaning with the actualization of its entire core. For example, the lexeme nin, once "bookish", froze as a variant of meaning adapted to the colloquial speech elements due to the strengthening of such negative semes as avarice, gluttony, extortion, adaptability, manipulation. Repetition and pleonasm are stylistic figures that further reinforce such a characteristic feature of Ukrainians as expressiveness coupled with an explicit proclivity to judge people and phenomena. Such Old Ky-

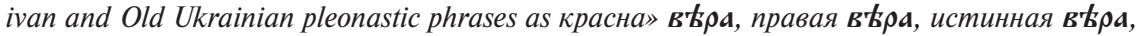
чистая $\mathbf{B} \mathbf{b} \rho \mathbf{a}$ could contribute to fixing the meaning religionin the lexeme $\mathbf{B} \mathbf{6} \rho \mathbf{a}$ (originally truth).

Key words: semantics, religious vocabulary, expressive component of meaning, stylistic connotation, pleonasm.

\section{Вступ}

Терміни, хоч як дбають про підтримання властивих їм термінологійних рис, «зазнають загальної долі слів - у своєму історичному житті і вони не уникають впливу тих чи інших обставин, які розхитують початкову домовленість щодо значень, які вкладаються в терміни...» (Булаховський, 1955: 20). За межами фахової сфери відбувається «вживлення» вузькогалузевої лексики 
в загальну мову: а) узуалізація термінного значення, або функціональне термінування, - поступове входження слова із термінним значенням до складу загальної мови; б) детермінування - перетворення терміна на загальновживане слово за потреби заповнити лакуну в певному семантичному полі. Термінні лексеми втрачають у живомовній стихії частину своєї вихідної семантики, причому залишок «семантичної пам'яті» може бути різним.

Мотивована похідна лексика постійно перебуває під пильною увагою українських мовознавців (Білецький, 2012; Іващенко, 2014; Кабиш, 2007; Карпіловська, 2010; Ковалик, 2008; Кочан, 2007; Мазурик, 2002; Мацько, 2000; Мельничук, 1981; Муромцева, 1985; Русанівський, 1983; Стишов, 2005; Струганець, 2002; Таран, 2011; Тараненко, 2015 та ін.). І це цілком зрозуміло, адже «саме мотивовані слова, або слова з подвійною референцією, становлять найпотужніший динамічний шар у лексиконі будь-якої мови» (Клименко, 2008: 35). Високий рівень проникності за межі свого звичного стилю нині, після тривалого перебування на периферії суспільної свідомості, має релігійна лексика, хоча в українській мові вона завжди була відкритою системою, добре відшліфованою завдяки активному використанню. Цей лексичний шар цілком справедливо відносять до тих, «що безпосередньо відображають найактивніші вияви сучасного життя. Такими елементами є ті слова, які доволі умовно можна назвати «термінними» (Исаченко, 1958: 336), а не побутова лексика з її виразним «субстратом» чи «адстратом» (Карпіловська, 2010: 94).

Незважаючи на пожвавлену зацікавленість функціонуванням релігійної лексики поза вузькопрофесійним сегментом комунікації (Браїлко, 2005; Колесник, 2018; Навальна, 2019; Піддубна, 2018; Скаб, 2015 та ін.), актуальним і досі $€$ питання актуалізації релігійної лексики в умовах її стильової переорганізації - в розмовно-побутовому, художньому, публіцистичному, мас-медійному українському мовленні. Мета цього дослідження - з'ясування ролі експресії в стильовій переорієнтації релігійних лексем, що зберігають свої релігійні значення поза релігійним дискурсом. До аналізу не ввійшли випадки десемантизації релігійної лексики в процесі іії безперебійного повсякденного використання у вигуках.

\section{Методи дослідження}

Для відновлення попереднього розвитку релігійної лексики, визначення давності виникнення того чи того значення залучено елементи методики зовнішньої реконструкції порівняльно-історичного методу, що поєднані 3 прийомами описового методу. Компонентний аналіз удоступнив розуміння видозміни семантики релігійних одиниць, функціональний - сприяв інтерпретації їхніх семантико-стилістичних параметрів.

\section{Результати дослідження}

Спеціальні лексеми в невластивій для них сфері втрачають жорстку системність і починають функціонувати як звичайні одиниці. Стилістичне збіднення релігійної семантики пов'язане передусім із прагненням мовців передати високий ступінь вияву почуттів й емоцій, чого досягають за допомогою 
підсилення окремих сем на тлі актуалізації всього ядра значення, змінивши конфігурацію загального інформаційного спектру через пристосування до нової емоційно-психологічної сфери впливу на адресата й орієнтування на відповідну мовленнєву ситуацію поза релігійною сферою. I тільки Бог - одвічне прибіжище душ людських - ие та соломинка, за якуя хочу вхопитись, зависаючи над прірвою (І. Багряний) - у цьому філософському міркуванні про сенс життя («Бог - соломинка») лексема Бог «здатна проспективно повідомляти про емоційно насичений текст із рисами піднесеності, урочистості» (Браїлко, 2005: 10). Тут підсилено низку сем ('милосердець', 'рятівник', 'надійність', 'радість') на тлі актуалізованого ядра прямого значення релігійної номінації Бог ('особа', 'надприродність', 'першопочаток', 'всемогутність' та ін.), завдяки чому відтворено стан духовного піднесення героя, трансцендентне заглиблення в проблему першосутності, святкову атмосферу світосприйняття, поетичність мислення.

Інший стилістичний відтінок, зокрема розмовності, з'явився, наприклад, у релігійній лексемі nin: за цим словом мовці закріпили суспільну зневагу до поведінки та вчинків священика, яку не могла не супроводжувати експресія - інтенсифікація виразності, «збільшення вражаючої сили сказаного 〈...>, надання йому особливої психологічно мотивованої піднесеності» (Чабаненко, 2002: 7). Розлад законів церковного життя, зарозумілість і хабарництво святих отців відобразилися на зміні давнього пошанувального звертання «ти» до духівників, як до Бога, офіційним, «лакувальним» «ви» (Колесов, 1988: 219). Якщо до особи духовного сану в XVII ст. ще зверталися на «ти» (Радуйся, отие наш і наставниче, Феодосію! («Повість минулих літ»); Ссли же ваша милость опарить каплана, потреба ще и на прачку, а ты, бъдный попе руский, мусищ и з законною нендзю клепати, неборачку (Г. Смотрицький); Пастирю душевний, попе ізбранний, Людей просвіщати од бога данний. (I. Пастелій), то в мовленні літературних героїв XVIII ст. подекуди вже з'явилося соціально-регулятивне «ви» (Набрав бідний Кирик гроші до кармана, пішов назад до пана, а од пана до попа: «Добродію, добродію, чи не могли б меї дитини сховати? Що ви схочете за похорони взяти?» попинкою (Сатир.-гумор. вірш), із чого можемо припустити початок усвідомлення дистанції між священиками і прихожанами.

У романі «Чорна рада» П. Куліша, визнаного критиками як перший великий український історичний роман, грунтований на ретельному вивченні історії подій та мови XVII ст., лексеми nin, панотець, отець звичайно є рівноцінними синонімами у стилістичному плані. Так, Кирило Тур урочисто, 3 почестями знайомить присутніх зі своїм гостем, представляючи його попом: - Ось мій гість!... Се, коли хочете знати, син паволоцького попа, той самий, що, як стукнувсь ізо мною за Києвом, що аж поле всміхнулось. Черевань, частуючи колишнього священика Шрама, шанобливо говорить про попів, ампліфікуючи при цьому синонімійні конструкції: - Моя премудрость, бгатику (братику. - А. К.),- сказав Черевань, - знає тільки налити та випити; а вам собі мізкувати, як хотя. На те ви попи, на те ви мужі совіта, на те 
ви народні голови. На захист православних священиків церковний староста сердито звертається до ксьондза: От ви й дожартувались із своєю унією! Отсе вам у наших попів хавтуру одбивати! Кирило Тур, дізнавшись про чорні наміри Тетері нашкодити його побратимові Шраму (священикові), мчить йому на допомогу зі словами: «Постривай, попе, ще, може, вернемо сокола з клітки». До дружини священика, своєї сестри, у «Марусі Богуславці» брат звертається: Попаде, з радощів тобі признаюсь, Що я - твій брат Івась.

Однак вокативи попе, попаде у творах П. Куліша, за нашими спостереженнями, були вже обмеженими, незважаючи на активне функціонування цієї лексеми в інших відмінкових формах. Здебільшого літературні персонажі користуються апелятивними формами панотче та отче, обминаючи поnе. Більшість мікроконтекстів із лексемами панотець і отець - це апелятиви, хоча кількісну перевагу з-поміж назв священика має саме лексема $\operatorname{nin}$, що підводить до думки про зародження стилістичної диференціації в запозиченій лексемі nin на відміну від власне українських відповідників панотець, отець, батюшка. Порівняння показників мінімальної кількості вибірок указаних номінацій у прозових творах радянської доби дає змогу пересвідчитися в закріпленні саме цієї тенденції, оскільки в одному з опрацьованих творів лексему nin, залучено щонайменше 27 разів, отець - 17 (але цей показник стосується й інших значень!), батюшка - 5, панотець - 3; а коефіцієнт частоти апелятивів інший: поnе - 0,0007, батюшко - 0,0028, отче - 0,0092) (Частотний, 1981). Якщо у творах кінця XIX - початку XX ст., за нашим фактичним матеріалом, використання слова $\operatorname{nin}$ у розмові з духівником або в його присутності вважали некоректним (лише подумки: «Оберни-ко-си, nопе, глипни ми в очи, та й скажи, що брешу...» (М. Черемшина), то в радянський час образа священика стала явищем закономірним. Мовним індикатором зміни ставлення до особи духовного сану став перехід з «ви» до «ти», оскільки «тикання» особі, якій раніше «викали», звичайно означає погіршення ставлення до неї (Скаб, 2003: 26): Попе! Вимітайся з храму Божого! (В. Міняйло), а також використання фамільярних форм батя, папаша, утворених, очевидно, від російського батюшка: - 3 тебе був би хороший конокрад, батя, або бандит, а не піп... (О. Копиленко); Обручати не будеш, батя? (П. Панч); - Папаша, ви б молебень відслужили, щоб хоч на два дні бог дірку заткнув: дві десятини сіна гниє в покосах (П. Панч).

Яскравим свідченням закріплення негативних характеристик особи священика за словом nin є епізод розмови Єви, дочки отця Захарія, та її нареченого Юліана в романі «Апостол черні» О. Кобилянської: - Я уявляла собі тебе не інакше як ученим, професором, урядовцем, військовим, усім іншим, але ніколи попом! Ні, ніколи попом! - Попом?- повторив Юліан придушеним голосом. - Сво, схаменися, що говориш? Чим є твій батько? Не священиком? На стилістичне забарвлення лексеми піn указує й уривок із роману I. Вільде «Сестри Річинські»: До вечора вже все село знало, що куми не принесли до хреста курок і калачів. Проте піn (вже не отець) мусив охрестити дитину, бо немає такого права, щоб за хрест доплачувати натурою. 
Пройшовши шлях від книжності до народності, лексема піп «застигла» як варіант значення, адаптований до народно-розмовної стихії (Словник, 1970-1980; Словник, 2012).

Стилістичні фігури різних видів повтору - це ефективні засоби формування експресивності, «що підтримує загострену увагу, активізує мислення людини, викликає напругу почуттів у слухача або читача» (Чабаненко, 2002: 7). Поширеними є використання буквальних повторів релігійних лексем та плеоназму, які демонструють особливу емоційність українського народу (в I. Вишенського: ГАє который 3 вас священство по закону узаконеному постГк?; нечнстыХ нечнстейшеє жнтне; крестом Хрнстовым, АО церкви прншедши, Хрестнтнся не сором'йто; у фразеології: Хрестом-Богом благати (молити) - «Настійно просити когось, домагаючись чого-небудь» (Фразеологічний, 1999: 34).

Розглянемо детальніше явище плеоназму на прикладі лексеми вњра, що первісно означала «істина, правда» (Етимологічний, 1982:402). Українцям це значення близьке й досі, адже збереглося в сучасній фразеології, що акумулює «багато фактів духовної культури, про які ми ніколи б не здогадались, якщо б те або те слово чи вислів не слугувало зарубинкою в нашій національній пам'яті» (Мокиенко, 2007: 97-198): фразеологізм вірою і правдою служити (догоджати і т. ін.) «з усією відданістю служити і т. ін. комусь» (Словник, 1970-1980: 679) подібний до інших українських фольклорних елементів: щастя-доля, цілющий-живущий, туга-печаль.

У пам'ятках Київської Русі лексема в Һра функціонувала в значеннях: «правда, істина», «упевненість», «присяга, клятва», «довір'я» «усвідомлення Божого закону, релігія» (Срезневский, 1893: 490). Розвиток цих значень М. Шанський відтворює так: «"правда, істина' $\rightarrow$ 'клятва, обіцянка' (тобто 'запевнення кого-небудь в істинності'; давньоісландське $V a ̂ r-$ богиня обітниці; рос. уверять, польське wiarac' 'клястися') $\rightarrow$ 'віра, упевненість' і як конкретизація останнього значення - релігійне значення (віра в Бога)» (Этимологический, 1963: 53-54). Із християнізацією в давньокиївських пам'ятках лексему в Бра мовці супроводжували означенням красна, утворюючи плеоназм красна в \$ра (краснага єсть в вра Хва̂ (Німчук, 2015: 251), маючи на увазі християнську істину. Аналогічне явище спостерігаємо у XVIII ст., коли плеоназмом правая вЊра, нстннная вЊра, чнстая вЊра аКцентували вже на православній правді: От сего үБо, впадающе в темность

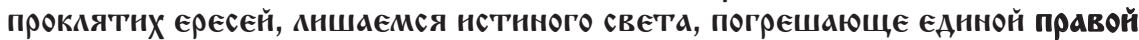
вЊры (В. Суразький); ...мнящнх нстннную въру оврьсти (Г. Смотриць-

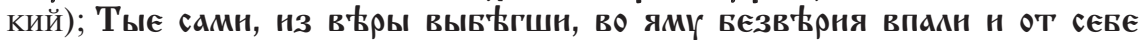

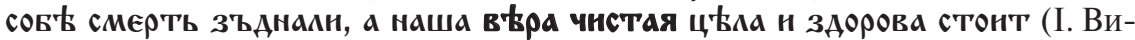
шенський). Звідси і лексема правовьрняе: трекАятни от церкве и закона

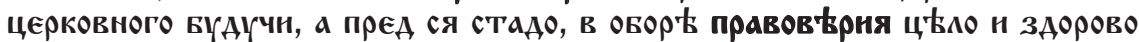
стоячеє, ХУАнте! (I. Вишенський). У вказаних творах Г. Смотрицького, В. Суразького, I. Вишенського та ін. натрапляємо на лексему в ра і без цих конкретизаторів, яка означає православні цінності, а неузагальнене, звичне 
для сучасного мовця, значення «релігія», адже у полемічних текстах ішлося про боротьбу православ'я з католицизмом та протестантизмом, а не захист від атеїзму: По прннятню же АЦХА святого уже все в БАают <...> спасеннем мюдскнм (з невњрства АО вњры прнводячн) шафуют (В. Суразький); Чн

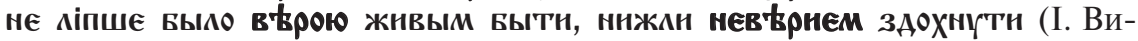
шенський). Лексеми невњрный, невьрнє, невњрство, як і вєзвьрнє

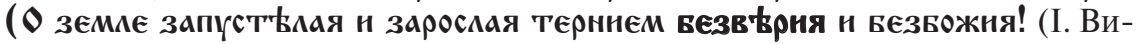
шенський) містили сему 'поза православною істиною', а не 'атеїстичний'. Плеонастичні словосполучення нстннная в рра / правая в правов ьрнє, вважаємо вишуканою формою звернення талановитих риторів до первісної семантики лексеми в фра. Сьогодні під впливом багатоконфесійності не лише в українській, а й в інших мовах слово віра має розширене значення «релігія»: дієприкметник від wierzyć, а саме wierzacy, у польській мові став синонімом до католик - рідше християнин загалом (Nagórko, 2000: 47).

\section{Висновки}

Поза релігійною сферою експресія супроводжує використання лексем у релігійних значеннях, стимулюючи стильову переорганізацію цих одиниць. Характер експресії впливає на появу нових стилістичних відтінків («нейтральне $\rightarrow$ поетичне, піднесено-урочисте, розмовне, оцінне та ін.») у значеннях, які з'являються на різних етапах розвитку релігійних лексем завдяки підсиленню окремих сем на тлі актуалізації всього ядра значення. Повтор і плеоназм є тими стилістичними фігурами, що слугують увиразненню притаманної українцям риси експресивності, поєднаної із критичною оцінкою людей і явищ. Саме такі давньокиївські та староукраїнські плеонастичні словосполучення, як краснаға вњра, правая вњра, нстннная вњра, чнстая в ьра могли сприяти закріпленню в лексемі вњра (первісно «істина, правда») значення «релігія».

\section{ЛІТЕРАТУРА}

1. Білецький В. О. Вибрані твори / упоряд. Н. Ф. Клименко, Є. А. Карпіловська, А. О. Савенко. Київ: Вид. дім Д. Бураго, 2012. С. 475-476. 2. Браїлко Ю. І. Конфесійна лексика у творчості українських поетів 60-80-х років XX століття (семантико-стилістичний аспект): автореф. дис. на здобуття наук. ступеня канд. філол. наук: спец. 10.02.01«Українська мова» / Нац. пед. ун-т ім. М. П. Драгоманова. Київ, 2005. 20 с. 3. Булаховський Л. А. Нариси з загального мовознавства. Київ: Рад. шк., 1955. 248 с. 4. Етимологічний словник української мови: у 7 т. / гол. ред. О. С. Мельничук. Київ: Наук. думка, 1982. Т. 1: А-Г. 631 с. 5. Исаченко А. В. К вопросу о структурной типологии словарного состава славянских литературных языков. Slavia. Praha: ČSAV, 1958. Roč. XXVII. Seš. 3. S. 334-352. 6. Іващенко В. Л. Основні напрями досліджень у термінознавстві кінця XX - початку XXI століть. Вісник Національного університеmу «Львівська політехніка». Проблеми української термінології. 2014. № 791. С. 22-26. 7. Кабиш О. О. Зміни в семантичній структурі та функціонуванні маркованої лексики: автореф. дис. на здобуття наук. ступеня канд. філол. наук: спец. 10.02.01 «Українська мова» / Нац. пед. ун-т ім. М. П. Драгоманова. Київ, 2007. 22 с. 8. Карпіловська Є. А. Нова 
Україна у словотвірній номінації: зміни у мовному «кресленні» світу. Відображення історії та культури народу в словотворенні: доповіді II Міжнар. наук. конф. Комісії зі слов'ян. словотвор. при Міжнар. комітеті славістів (25-28 травня 2010 р.). Київ: Вид. дім Д. Бураго, 2010. С. 91-109. 9. Клименко Н. Ф., Карпіловська Е. А., Кислюк Л. П. Динамічні процеси в сучасному українському лексиконі: монографія. Київ: Вид. дім Дмитра Бураго, 2008. 336 с. 10. Ковалик I. І. Питання українського і слов'янського мовознавства: вибрані праці: ч. ІІ. / упоряд. 3. Терлак. Львів - Івано-Франківськ, 2008. 496 с. 11. Колесник Н. С Християнська онімія як складник фольклоронімного простору: склад, структура, основні характеристики. Онімний простір украӥнського пісенного фольклору: семантичний, структурний та функціональний аспекти: дис. ... доктор. філол. наук: 10.02.01. Чернівці, 2018. С. 169-310. 12. Колесов В. В. Культура речи культура поведения. Ленинград: Лениздат, 1988. 271 с. 13. Кочан I. Терміни та професійна лексика кінця XX - початку XXI століття. Українська термінологія і сучасність: зб. наук. праць. 2007. Вип. 7. С. 69-73. 14. Мазурик Д. В. Інноваційні процеси в лексиці сучасної української літературної мови (90-і роки ХХ ст.): автореф. дис. на здобуття наук. ступеня канд. філол. наук: спец. 10.02.01 «Українська мова» / Львів. нац. ун-т ім. І. Франка. Львів, 2002. 20 с. 15. Мацько Л. Українська мова в кінці ХХ ст. (зміни в лексиці). Дивослово. 2000. № 4. С. 5-20. 16. Мельничук О. С. Розвиток мови як реальної системи. Мовознавство. 1981. № 2. С. 22-34. 17. Мокиенко В. М. Образы русской речи: историко-этимологические очерки фразеологии. Москва: Флинта, 2007. 464 с. 18. Муромцева О. Г. Розвиток лексики української літературної мови в другій половині XIX на початку ХХ ст. Харків: Вид-во при ХДУ «Вища школа», 1985. 152 с. 19. Навальна М. Конфесійна лексика в мові сучасної української художньої літератури. Хрестоматия теолингвистики: m. 2: сб. ст. /под ред. А. К. Гадомского и др. Ульяновск: ООО «Мастер Студия», 2019. С. 266-275. 20. Німчук В. Хрестоматія з історії української мови ХXIII ст. Житомир: Полісся, 2015. 352 с. 21. Піддубна Н. В. Бібліїзми й релігійна лексика та фразеологія: спроба розмежування понять. Лінгвістичні дослідження: зб. наук. праць ХНПУ ім. Г. С. Сковороди. 2018. Вип. 47. С. 50-56. URL: https://doi.org/10.5281/ zenodo.1203849. 22. Русанівський В. М. Семантичні процеси розвитку української лексики. Історія української мови. Лексика і фразеологія /відп. ред. В. М. Русанівський. Київ: Наук. думка, 1983. С. 660-715. 23. Скаб М. С. Прагматика апеляції в українській мові: навч. посіб. Чернівці: Рута, 2003. 80 с. 24. Скаб М. Традиційне і нове у використанні української біблійної фразеології. Dialog z tradycja. T. III : Język - komunikacja - kultura / podred. nauk. R. Dźwigot i I. Steczko. Kraków: Collegium Columbinum, 2015.S. 97-109. 25. Словник української мови / відп. ред. В. В. Жайворонок. Київ: Вид. центр «Просвіта», 2012. 1316 с. 26. Словник української мови: в 11 т. / гол. ред. І. К. Білодід. Київ: Наук. думка, 1970-1980. 27. Срезневский И. И. Матеріалы для словаря древне-русскаго языка по письменнымъ памятникамъ. Санкт-Петербургъ: Тип. Императ. Акад. Наукъ, 1893-1912. 28. Стишов О. А. Українська лексика кінця ХХ століття. Київ: Пугач, 2005. 388 с. 29. Струганець Л. В. Процеси актуалізації та пасивізації лексико-семантичних засобів в українській літературній мові кінця XX століття. Слово. Стиль. Норма: зб. наук. пр. / відп. ред. Н. М. Сологуб. Київ, 2002. С. 53-57. 30. Таран А. Конкурування номінацій у сучасній українській літературній мові: тенденції стабілізації нової лексики. Черкаси: Вид. Чабаненко Ю., 2011. 232 с. 31. Тараненко О. О. Актуалізовані моделі в системі словотворення сучасної української мови (кінець ХХ - XXI ст.): монографія. Київ: Вид. дім Дмитра Бураго, 2015. 248 с. 32. Фразеологічний словник української мови: у 2 кн./ В. М. Білоноженко, В. О. Винник, І. С. Гнатюк та ін. Київ: Наук. думка, 1999. 980 с. 33. Чабаненко В. А. Стилістика експресивних засобів 
української мови. Запоріжжя: ЗНУ, 2002. 351 с. 34. Частотний словник сучасної української мови художньої прози: у 2 т. / гол. ред. В. С. Перебийніс. Київ: Наук. думка, 1981. 35. Этимологический словарь русского языка: у 2 т. / под ред. Н. М. Шанского (вып. 1-8); А. Ф. Журавлева и Н. М. Шанского (вып. 9-10). Москва: Изд-во Моск. ун-та, 1963-2007. 36. Nagórko A. Świecki język - przeobrażenia semantyczne słownictwa religijnego (na materiale niemieckim). Biuletyn polskiego towarzystwa językoznawczego. Bulletin de la societe polonaise de linguistique. Zeszyt LVI - Fascicule LVI. Warszawa: Wydawnictwo Energeia, 2000. S. 39-48.

\section{REFERENCES}

1. Biletskyi, V. O. (2012). Vybrani tvory [Selected Works]. N. F. Klymenko (Ed.). Kyiv: Vyd. dim D. Buraho [in Ukrainian]. 2. Brailko, Yu. I. (2005). Konfesiina leksyka u tvorchosti ukrainskykh poetiv 60-80-kh rokiv $\mathrm{KhKh}$ stolittia (semantyko-stylistychnyi aspekt) [Confessional lexicon in the works of Ukrainian poets of the 1960s-80s (semantic and stylistic aspects)]. Extended abstract of candidate's thesis. Kyiv: Nats. ped. Un-t im. M. P. Drahomanova [in Ukrainian]. 3. Bulakhovskyi, L. A. (1955). Narysy z zahalnoho movoznavstva [Essays on general linguistics]. Kyiv: Rad. shk. [in Ukrainian]. 4. Melnychuk, O. S. (Eds.). (1982). Etymolohichnyi slovnyk ukrainskoi movy [Etymological Dictionary of the Ukrainian Language]. (Vol. 1-7). Kyiv: Nauk. Dumka [in Ukrainian]. 5. Ysachenko, A. V. (1958). K voprosu o strukturnoi typolohyy slovarnoho sostava slavianskykh lyteraturnыkh yazыkov [On the question of the structural typology of the vocabulary of Slavic literary languages]. Slavia, roč. XXVII, seš. 3, 334-352 [in Czechoslovakia]. 6. Ivashchenko, V. L. (2014). Osnovni napriamy doslidzhen u terminoznavstvi kintsia XX - pochatku XXI stolit [The main directions of research in terminology studies in the late $20^{\text {th }}$ century and early $21^{\text {st }}$ century]. Visnyk Natsionalnoho universytetu «Lvivska politekhnika». Problemy ukrainskoi terminolohiiBulletin of the Lviv Polytechnic National University. Problems of Ukrainian terminology, 791, 22-26 [in Ukrainian]. 7. Kabysh, O. O. (2007). Zminy v semantychnii strukturi ta funktsionuvanni markovanoi leksyky [Changes in the semantic structure and function of marked vocabulary]. Extended abstract of candidate's thesis. Kyiv: Nats. ped. un-t im. M. P. Drahomanova [inUkrainian]. 8. Karpilovska, Ye. A. (2010). Nova Ukraina u slovotvirnii nominatsii: zminy u movnomu «kreslenni» svitu [New Ukraine in the word-building nomination: changes in the language's «drawing» of the world.]. Vidobrazhennia istorii ta kultury narodu $v$ slovotvorenni. Dopovidi II Mizhnarodnoi naukovoi konferentsii Komisii zi slovianskoho slovotvorennia pry Mizhnarodnomu komiteti slavistiv (25-28 travnia 2010 r.). Representation of the history and culture of the people in word formation. Reports of the Second International Scientific Conference of the Commission on Slavic Formation at the International Committee of Slavists (May 25-28, 2010).(pp. 91-109). Kyiv: Vyd. dimD. Buraho [in Ukrainian]. 9. Klymenko, N. F., Karpilovska, Ye. A., Kysliuk, L. P. (2008). Dynamichni protsesy $v$ suchasnomu ukrainskomu leksykoni [Dynamic processes in the modern Ukrainian lexicon]. Kyiv: Vyd. dimD. Buraho [in Ukrainian]. 10. Kovalyk, I. I. (2008). Pytannia ukrainskoho i slovianskoho movoznavstva: vybrani pratsi. [Issues of Ukrainian and Slavic linguistics: selected works]. Z. Terlak(Ed.). Lviv - Ivano-Frankivsk [in Ukrainian]. 11. Kolesnyk, N. S. (2018). Khrystyianska onimiia yak skladnyk folkloronimnoho prostoru: sklad, struktura, osnovni kharakterystyky [Christian onymy as a component of folkloronym space: composition, structure, main characteristics]. Kolesnyk N. S. Onimnyi prostir ukrainskoho pisennoho folkloru: semantychnyi, strukturnyi ta funktsionalnyi aspekty - Onymic space of the Ukrainian folk songs: semantic, structural and functional aspects. Doctor's thesis (pp. 169-310). Chernivtsi: Chernivetskyi nats. un-t im. Yuriia Fedkovycha [in Ukrainian]. 
12. Kolesov, V. V. (1988). Kultura rechy - kultura povedenyia [Speech culture - culture of behavior]. Lenynhrad: Lenyzdat [in Ukrainian]. 13. Kochan, I. (2007). Terminy ta profesiina leksyka kintsia XX - pochatku XXI stolittia [Terms and professional vocabulary in the late $20^{\text {th }}$ century and early $21^{\text {st }}$ century]. Ukrainska terminolohiia $i$ suchasnist - Ukrainian terminology and modernity, 8, 69-73 [in Ukrainian]. 14. Mazuryk, D. V. (2002). Innovatsiini protsesy v leksytsi suchasnoi ukrainskoi literaturnoi movy (90-i roky XX st.) [Innovative processes in the vocabulary of the modern Ukrainian literary language (the 1990s).]. Extended abstract of candidate's thesis. Lviv: Nats. un-t im. I. Franka [in Ukrainian]. 15. Matsko, L. (2000). Ukrainska mova v kintsi XX st. (zminy v leksytsi) [The Ukrainian language at the end of the twentieth century (changes in the vocabulary)]. Dyvoslovo-Wonderword, 4, 5-20 [in Ukrainian]. 16. Melnychuk, O. S. (1981). Rozvytok movy yak realnoi systemy [The development of language as a real system]. Movoznavstvo - Linguistics, 2, 22-34 [in Ukrainian]. 17. Mokyenko, V. M. (2007). Obrazb russkoirechy: ystoryko-эtymolohycheskye ocherky frazeolohyy [Images of the Russian language: historical and etymological essays of phraseology]. Moskva: Flynta [in Russian]. 18. Muromtseva, O. H. (1985). Rozvytok leksyky ukrainskoi literaturnoi movy $v$ druhii polovyni XIX - na pochatku XX st. [Development of the vocabulary of the Ukrainian literary language in the second half of the $19^{\text {th }}$ century and early $20^{\text {th }}$ century]. Kh.: Vyd-vo pry KhDU «Vyshcha shkola» [in Ukrainian]. 19. Navalna, M. (2019). Konfesiina leksyka v movi suchasnoi ukrainskoi khudozhnoi literatury [Confessional vocabulary in the language of the contemporary Ukrainian fiction]. Khrestomatyia teolynhvystyky: $m$. $2-$ Anthology of theolinguistics: vol. 2. A. K. Hadomskoho (Ed.). Ulianovsk: OOO «Master Studyia» [in Poland]. 20. Nimchuk, V.(2015). Khrestomatiia $z$ istorii ukrainskoi movy XXII st. [The textbook on the history of the Ukrainian language of the $10^{\text {th }}-13^{\text {th }}$ centuries]. Zhytomyr: Polissia [in Ukrainian]. 21. Piddubna, N. V. (2018). Bibliizmy y relihiina leksyka ta frazeolohiia: sproba rozmezhuvannia poniat [Bibleisms and religious vocabulary and phraseology: an attempt to distinguish between concepts]. Linhvistychni doslidzhennia Linguistic study, 47, 50-56 [in Ukrainian] Retrieved from https://doi.org/10.5281/ zenodo.1203849. 22. Rusanivskyi, V. M. (1983). Semantychni protsesy rozvytku ukrainskoi leksyky [Semantic processes of the development of the Ukrainian vocabulary]. Istoriia ukrainskoi movy. Leksyka i frazeolohiia - History of the Ukrainian language. Lexics and phraseology. V. M. Rusanivskyi (Ed.), (pp. 660-715). Kyiv: Nauk. dumka [in Ukrainian]. 23. Skab, M. S. (2003). Prahmatyka apeliatsii v ukrainskii movi [Pragmatics of the appeal in the Ukrainian language]. Chernivtsi: Ruta [in Ukrainian]. 24. Skab, M. (2015). Tradytsiine i nove u vykorystanni ukrainskoi bibliinoi frazeolohii [Traditional and new in the use of the Ukrainian biblical phraseology]. Dialog z tradycja. T. III: Język - komunikacja - kultura. R. Dźwigoł i I. Steczko. Kraków: Collegium Columbinum [in Poland]. 25. Zhaivoronok, V. V. (Eds.). (2012). Slovnyk ukrainskoi movy [Dictionary of the Ukrainian Language]. Kyiv: Vydavnychyi tsentr «Prosvita» [in Ukrainian]. 26. Bilodid, I. K. (Eds.). (1970-1980). Slovnyk ukrainskoi movy [Dictionary of the Ukrainian Language]. (Vol. 1-11). Kyiv: Nauk. dumka [in Ukrainian]. 27. Sreznevskyi, Y. Y. (1893-1912). Materialbl dlia slovaria drevne-russkaho yazblka po pysmennыmz pamiatnykamz [Materials for the dictionary of the Old Russian language on written records]. Sankt-Peterburhъ: Typ. Ymper. Akad. Naukъ [in Russian]. 28. Styshov, O. A. (2005). Ukrainska leksyka kintsia XX stolittia [Ukrainian vocabulary of the late twentieth century]. Kyiv: Puhach [in Ukrainian]. 29. Struhanets, L. V. (2002). Protsesy aktualizatsii ta pasyvizatsii leksyko semantychnykh zasobiv v ukrainskii literaturnii movi kintsia XX stolittia [Processes of actualization and passivisation of lexical and semantic means in the Ukrainian literary language at the end of the twentieth century]. Slovo. Styl. Norma-Word. Style. Norm N. M. Solohub (Eds.).Kyiv [in Ukrainian]. 30. Taran, A. (2011). Konkuruvannia nominatsii u 
suchasnii ukrainskii literaturnii movi: tendentsii stabilizatsii novoi leksyky /Competition of nominations in the modern Ukrainian literary language: tendencies of stabilization of the new vocabulary]. Cherkasy: Vydavets Chabanenko Yu. [in Ukrainian]. 31. Taranenko, O. O. (2015). Aktualizovani modeli v systemi slovotvorennia suchasnoi ukrainskoi movy (kinets XX XXI st.) [Actualized models in the system of word formation of the modern Ukrainian language (late twentieth century and the early twenty first century)].Kyiv: Vyd. dim Dmytra Buraho [in Ukrainian]. 32. Bilonozhenko, V. M., Vynnyk, V.O., Hnatiuk, I. S. (Ed.). (1999). Frazeolohichnyi slovnyk ukrainskoi movy [Phraseological Dictionary of the Ukrainian Language]. (Vol. 1-2). Kyiv: Nauk. dumka [in Ukrainian]. 33. Chabanenko, V. A. (2002). Stylistyka ekspresyvnykh zasobiv ukrainskoi movy [Stylistics of expressive means of the Ukrainian language]. Zaporizhzhia: ZNU [in Ukrainian]. 34. Perebyinis, V. S. (Eds.). (1981). Chastotnyi slovnyk suchasnoi ukrainskoi movy khudozhnoi prozy [Frequency Dictionary of the Modern Ukrainian Language of Fiction]. Kyiv: Nauk. dumka [in Ukrainian]. 35. Shanskyi, N. M. (vыp. 1-8), Zhuravlev, A. F., Shanskyi, N. M. (vыp. 9-10). (1963-2007). Эtymolohycheskyi slovar russkoho yazbka [Etymological Dictionary of the Russian Language]. (Vol. 1-2). Moskva: Yzd-vo Mosk. un-ta [in Russian]. 36. Nagórko, A. (2000). Świecki język - przeobrażenia semantyczne słownictwa religijnego (na materiale niemieckim). Biuletyn polskiego towarzystwa językoznawczego. Bulletin de la societe polonaise de linguistique. Zeszyt LVI - Fascicule LVI. Warszawa: Wydawnictwo Energeia [in Poland].

Ковтун Альбіна Анатолї̈вн - доктор філологічних наук, доцент, доцент кафедри історії та культури української мови, Чернівецький національний університет імені Юрія Федьковича; вул. Коцюбинського, 2, Чернівці, 58012, Україна.

Тел.: +38-095-380-73-33

E-mail: albkovtun500@gmail.com

http://orcid.org/0000-0002-0690-3265

Kovtun Albina Anatoliivna - Doctor of Philology, Associate Professor, Department of History and Culture of the Ukrainian Language, Yuri Fedkovych Chernivtsi National University; M. Kotsiubynskyi Str., 2, Chernivtsi, 58012, Ukraine.

Надійшла до редакції 28 лютого 2019 року 